\title{
Effect of supplementary irrigation on total antioxidant capacity and phenolic content of hazelnut
}

\author{
Tahsin TONKAZ ${ }^{\mathbb{D} 1}$ 1, Sümeyye ŞAHIN ${ }^{\mathbb{D} 2}$ 2, Saim Zeki BOSTAN ${ }^{\mathbb{D} 3}$ 3, Kürşat KORKMAZ ${ }^{\mathbb{D}} 4$ \\ 10rdu Üniversitesi, Ziraat Fakültesi, Ziraat Fakültesi, Biyosistem Mühendisliği, Ordu \\ ${ }^{2}$ Ordu Üniversitesi, Ziraat Fakültesi, Ziraat Fakültesi, Gıda Mühendisliği, Ordu \\ 30rdu Üniversitesi, Ziraat Fakültesi, Ziraat Fakültesi, Bahçe Bitkileri Bölümü, Ordu \\ ${ }^{4}$ Ordu Üniversitesi, Ziraat Fakültesi, Ziraat Fakültesi, Toprak Bilimi ve Bitki Besleme Bölümü, Ordu
}

Alınış tarihi: 16 Aralık 2019, Kabul tarihi: 30 Aralık 2019

Sorumlu yazar: Tahsin TONKAZ, e-posta: ttonkaz@hotmail.com

\begin{abstract}
Aim of this study was to investigate the effect of supplementary irrigation on the total antioxidative capacity and total phenolic content of hazelnuts. Orchard of hazelnut trees were irrigated at the different growth stages combinations. To determine antioxidative capacity, the samples were analyzed by the spectrophotometric assay using the stable DPPH radical. The total phenolic content was determined by the Folin-Ciocalteu assay. The results indicated that the total antioxidative capacity was affected by the irrigation conditions. The hazelnut kernels and defatted hazelnut kernels from irrigated at all growth stages showed the highest antioxidative capacity, while the lowest antioxidative activity was observed in control (no irrigation applied). On the contrary, the hazelnut kernel oil obtained from control induced higher antioxidative capacity than irrigated at the first growth stage. These spectrophotometrically measurements confirm that hazelnut kernels and their oils contain antioxidative components having different structural properties such as lipophilic and hydrophilic character and amounts of these compounds were changed by irrigation conditions. In contrast, any notable change of total phenolic content was observed in hazelnut samples, depending on the irrigation condition.
\end{abstract}

Key words: Hazelnut, irrigation, growth stages, antioxidative capacity, phenolic content

\section{Destekleme sulamanın findığın toplam antioksidan kapasitesi ve fenolik miktarına etkisi}

öz

Bu çalışmanın amacı, destekleme sulamanın fındığın toplam antioksidan kapasitesi ve fenolik içeriğine etkisini araştırmaktır. Fındık ağaçlarına farklı büyüme evrelerinde sulama yapılmıştır. Antioksidan kapasiteyi belirlemek için numuneler DPPH radikali ile spektrofotometrik bir yöntemle analiz edilmiştir. Toplam fenolik içeriği folin-ciocalteu metodu ile belirlenmiştir. Sonuçlar toplam antioksidan kapasitesinin sulamadan etkilendiğini göstermiștir. Gelişiminin bütün evrelerinde sulanmış (tam sulama) fındık vebu fındıklardan elde edilen yağı alınmış numuneler en yüksek antioksidan kapasite gösterirken, en düşük antioksidan aktivite kontrol gruplarında (sulama yapılmamış) gözlemlenmiştir. Buna karşın, kontrol gruplarına ait yağ örneklerinin antioksidan kapasitesi, gelişiminin ilk evresinde sulamaya tabi tutulan fındık örneklerinin yağlarının antioksidan kapasitesinden daha büyüktür. $\mathrm{Bu}$ spektrofotometrik ölçümler, fındık ve yağlarının, lipofilik ve hidrofilik gibi farklı yapısal özelliklere sahip olduğunu ve bu bileşiklerin miktarlarının sulama koşullarına göre değiştiğini doğrulamaktadır. Buna karşılık, sulamaya bağlı olarak, fındık örneklerinin toplam fenolik içeriğinde gözle görülür bir değişim gözlemlenmemiştir.

Anahtar kelimeler: Fındık, sulama, büyüme evreleri, antioksidan kapasite, fenolik içerik 


\section{Introduction}

Turkey, the motherland of hazelnut culture, is the biggest hazelnut producer country in the world (İslam, 2018). It was reported that the total hazelnut production in the world is over a billion ton and Turkey provides 67 percent of the global supply (FA0, 2019).

The major constituent of hazelnut is fat (about 60.0 $\%)$. Hazelnut oil is rich in unsaturated fatty acids, especially oleic acid which is a monounsaturated fatty acid (Crews et al., 2005; Koyuncu et al, 2005). Hazelnut oil is a good source of lipid-soluble vitamins such as vitamin E showing high antioxidant capacity and health benefits (Alasalvar et al., 2006; Amaral et al., 2006 Crews et al., 2005). In addition to vitamins, hazelnut contains several phytochemicals such as phenolic compounds which are soluble in water (hydrophilic) and have antioxidant activity. Due to its phytochemicals, hazelnuts have high antioxidant activity (Alasalvar and Shahidi, 2009; Altun et al. 2013; Arcan and Yemenicioğlu, 2009). In several studies, the total antioxidant capacity, total phenolic content and also phenolic and antioxidant active compounds in hazelnut have been reported (Altun et al. 2013; Arcan and Yemenicioğlu, 2009; Li and Parry, 2011). The irrigation influences the quality and quantity of product in agriculture (Schmidt and Zinkernagel, 2017). It has been shown that, the irrigation application enhanced the kernel growth and quantity of hazelnut (Cristofori et al, 2014; Külahçllar et al., 2018). However, the effect of irrigation on antioxidant capacity and phenolic content are not fully evaluated. Therefore, the aim of this study was to investigate the antioxidant capacity and phenolic content of hazelnut irrigated at the different growth stages combinations.

\section{Materials and Methods}

\section{Chemicals}

Trolox (6-hydroxy-2,5,7,8-tetramethylchroman-2carboxylic acid), DPPH (2,2-diphenyl-1picrylhydrazyl), sodium carbonate and gallic acid were purchased from Sigma-Aldrich (St. Louis, USA). Hexane, folin-ciocalteu, and n-Butanol were obtained from Merck (Darmstadt, Germany).

\section{Plant material and irrigation condition}

The samples were obtained from Tombul hazelnut orchard, about 100 years old, located in 40 $52^{\prime}$ latitude and $38^{\circ} 36^{\prime}$ longitude in Giresun province. The orchard is south-facing slope, with a gradient of $60 \%$. The drip irrigation was applied on hazelnut orchard during growth stages of kernels. Hazelnut "ocak" (multi-stemmed bushes) were irrigated during vegetation. The first stage of growth is the fruit set period after the fertilization (15-30 May). The second stage of growth is called the kernel development period (1-31 Jun). The third stage of growth is the preharvest period (1-31 July). Irrigation application stages are presented in Table 1.

Table 1 Irrigation applications during vegetation

\begin{tabular}{lc}
\hline Irrigation treatment & $\begin{array}{c}\text { Irrigation } \\
\text { amount (mm) }\end{array}$ \\
\hline Control; no irrigation; only rain feed & 0 \\
\hline Irrigation at the first stage of growth & 40 \\
\hline $\begin{array}{l}\text { Irrigation at the first and second stage (no } \\
\text { irrigation water applied because enough } \\
\text { rainfall at this stage) of growth }\end{array}$ & 41 \\
\hline $\begin{array}{l}\text { Irrigation at the first, second (no irrigation } \\
\text { water applied because enough rainfall at } \\
\text { this stage) and third stage of growth; full } \\
\text { irrigation; no water stress }\end{array}$ & 237 \\
\hline
\end{tabular}

After the harvest (hand-picked from branches) on August 19, 2016, hazelnuts were separated from its husks using a husker and dried under open air condition. The dried hazelnut shells were broken and removed from kernels. The hazelnut kernels were grounded prior to analysis.

\section{Extraction of oil and preparation of defatted samples}

Total fat in hazelnut kernels was extracted with nhexane by using Soxhalet extraction apparatus (Velp Ser 148, Milano, Italy) according to literature (Sahin et. al, 2019). The extracted oil was stored at $-18^{\circ} \mathrm{C}$ until to analysis. The defatted samples were obtained from the solid residue of Soxhalet extraction.

\section{Determination of total antioxidative activity}

To determine the antioxidant capacity of the hazelnut kernels, defatted hazelnut kernels, and hazelnut oils, the DPPH (2,2-diphenyl-1picrylhydrazyl) radical scavenging assay was performed by the method according to literature (Sahin, 2011). The absorbance was measured at 515 nm with a UV/Vis spectrophotometer (Perkin-Elmer 710 Bridgeport Avenue Shelton, CT 06484-4794, USA). Total antioxidant capacity was calculated using trolox standard curves and expressed as millimoles per liter trolox equivalents.

\section{Determination of total phenolic content}

Total phenol contents of hazelnut kernel and defatted hazelnut kernel extracts were determined 
by the Folin-Ciocalteu method described by Altun et al. (2013). The absorbance was recorded spectrophotochemically at $765 \mathrm{~nm}$. Gallic acid was the standard used to calculate total phenolic content.

\section{Data analysis}

The results of all analysis were expressed as means \pm standard deviation (SD) and the data were statistically analyzed using repeated measures oneway ANOVA. Following ANOVA, the Fisher pairwise comparisons test was used with significance levels $p$ $<0.05$.

\section{Results and Discussion}

The present study evaluated the total antioxidative capacity and total phenolic content in kernel, kernel oil and defatted kernel of hazelnut irrigated at the different growth stages combinations.

\section{Total antioxidant capacity}

Antioxidants inactivate the free radicals and inhibite oxidative stress, which is associated with some chronic and acute diseases, including cardiovascular diseases, cancer, and neurodegenerative diseases (Willcox et al., 2004). It has been reported that hazelnut is rich natural antioxidants (Alasalvar and Shahidi, 2009). Previous studies have shown that hazelnut exhibits high antioxidative activity in several assays (Altun et al., 2013; Arcan and Yemenicioğlu 2009; Contini et al., 2008; Delgado et al., 2010; Miraliakbari and Shahidi 2008; Li and Parry 2011; Yang et al., 2009). In the present study, the antioxidant capacity of hazelnut samples was analyzed by DPPH radical scavenging assay. The antioxidative capacity of hazelnut kernels was shown in Figure 1. The highest antioxidative capacity was observed in kernels of hazelnut from irrigated at all $\left(1^{\text {st }}, 2^{\text {nd }}\right.$ and $\left.3^{\text {rd }}\right)$ growth stages $(0.48 \pm 0.03 \mathrm{mmol}$ /L TE), while the hazelnut without irrigation showed the lowest antioxidant activity $(0.24 \pm 0.03 \mathrm{mmol} / \mathrm{L}$ TE). Total antioxidant capacity was increased twofold by irrigation at all growth stages. Among the defatted hazelnut kernels, hazelnuts, which were irrigated at all growth stages, exhibited the greatest antioxidant activity (Fig. 2). In the defatted hazelnut kernels, the total antioxidant capacity increased with increasing irrigation stages (Fig. 2).

Although previous studies demonstrated the positive impacts of irrigation on vegetative growth and yield characters of hazelnut (Cristofori et al, 2014; Külahçlar et al., 2018), the effects of irrigation on the amounts of bioactive compounds and antioxidant capacity of hazelnut are not yet reported. Lipan et al. (2019) observed that the antioxidant capacity of almonds was not affected by irrigation. Marin et al. (2009) investigated the effect of irrigation frequency on the amounts of antioxidant compounds in green and red peppers. They reported that the amount of vitamin $\mathrm{C}$, a water- soluble antioxidant, decreased in green pepper when increased the irrigation amount, whereas the content of lipid- soluble (lipophilic) antioxidants such as carotenoids was not affected by irrigation. On the other hand, there was no significant difference in the content of vitamin $\mathrm{C}$ between low and high irrigated red pepper, while the lipid-soluble carotenoids content was reduced by irrigation frequency at the red ripening stage. Similarly, Pernice et al. (2010) reported that the irrigation led to a decrease in lipid-soluble carotenoids content. In the present study, the antioxidant capacity of hazelnut oil was also decreased when irrigated at first growth stage of kernel (Fig. 3). The result observed can be explaned that hazelnut oil is rich in the lipid-soluble antioxidants, which were decreased by irrigation. It has been reported that hazelnut oil had high amount of vitamin E belonging to lipid-soluble antioxidants (Crews et al., 2005; Krist et al., 2008; Kornsteiner et al., 2006).

\section{Total phenolic content}

It was shown previously that some antioxidants in hazelnut have the phenolic structure (Altun et al., 2013). Total phenolic contents of hazelnut varied depending on cultivars and geographical origin (Altun et al., 2013; Li and Parry 2011; Sahin et al., 2017; Pelvan et al., 2012). Figure 4 showed total phenolic contents of hazelnut kernels. The amount of total phenolic content ranged from 0.145 to 0.161 $\mathrm{mmol} / \mathrm{L}$ GAE. It was found that there was no significant difference in total phenolic content between control (not irrigated) and irrigated samples. In addition, the amount of total phenolics in defatted hazelnut kernels did not change significantly related to irrigation application (Fig. 5). Recently, it has been reported that the total phenolic content of almond was not changed by irrigation (Lipan et al., 2019). Likewise, it has been shown that the content of total phenolics in red pepper was not affected by irrigation frequency. However, the high irrigated green pepper had a lower phenolic content compared to the low irrigated green pepper (Marin et al., 2009). 


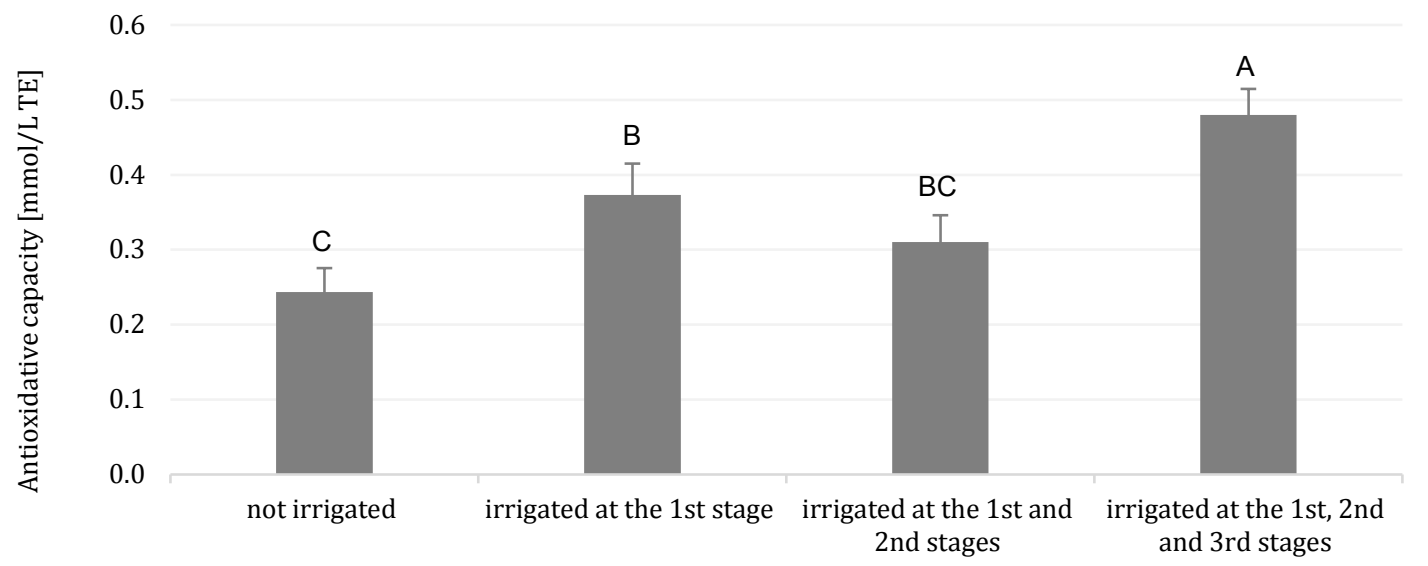

Figure 1 Total antioxidant capacity of hazelnuts irrigated at the different growth stages combinations. The values indicated by different letters are different from each other at $\mathrm{p}<0.05$ level.

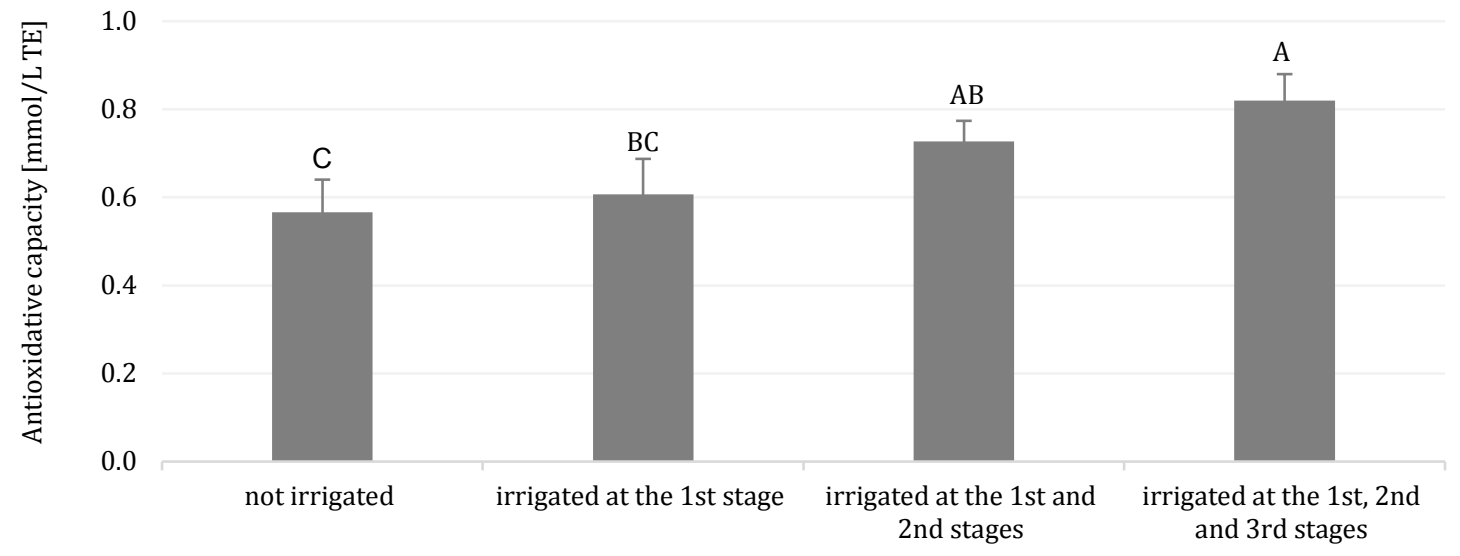

Figure 2 Total antioxidant capacity of defatted hazelnut kernels irrigated at the different growth stages combinations. The values indicated by different letters are different from each other at $\mathrm{p}<0.05$ level.

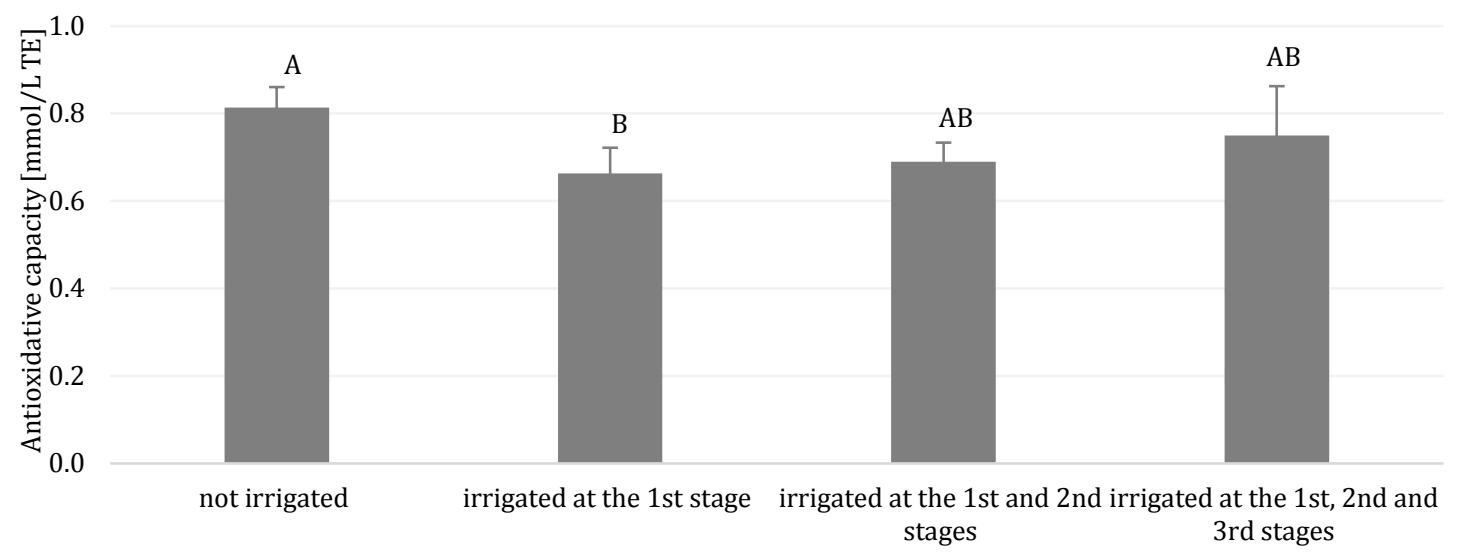

Figure 3 Total antioxidant capacity of the oils of hazelnuts irrigated at the different growth stages combinations. The values indicated by different letters are different from each other at $p<0.05$ level. 


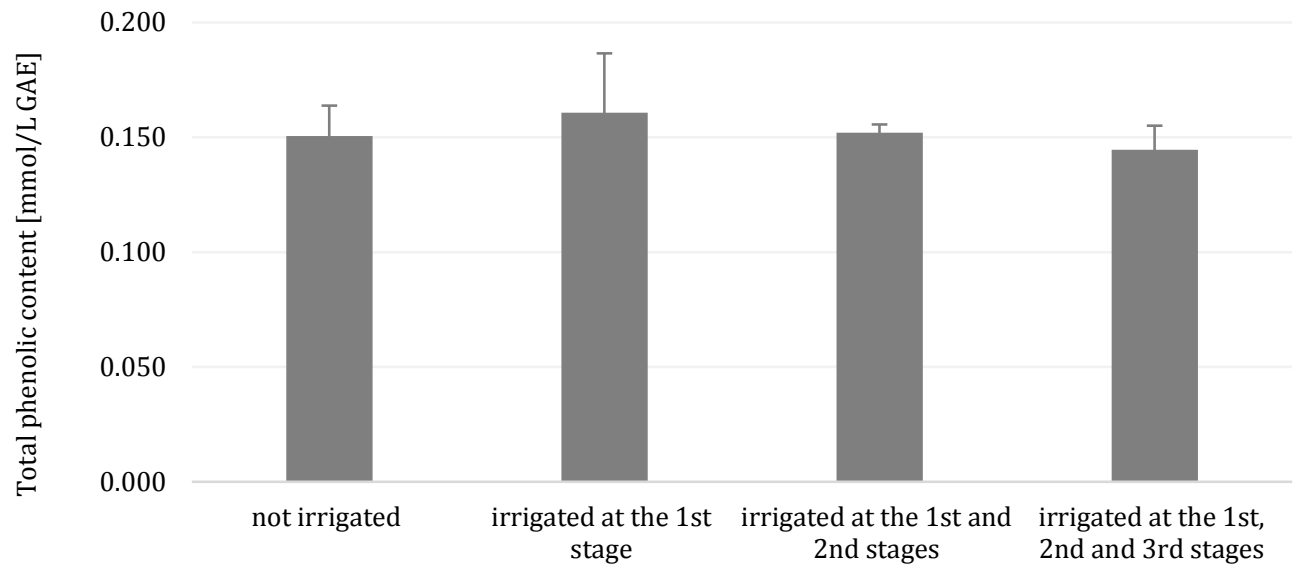

Figure 4 Total phenolic contents of hazelnuts irrigated at the different growth stages combinations.

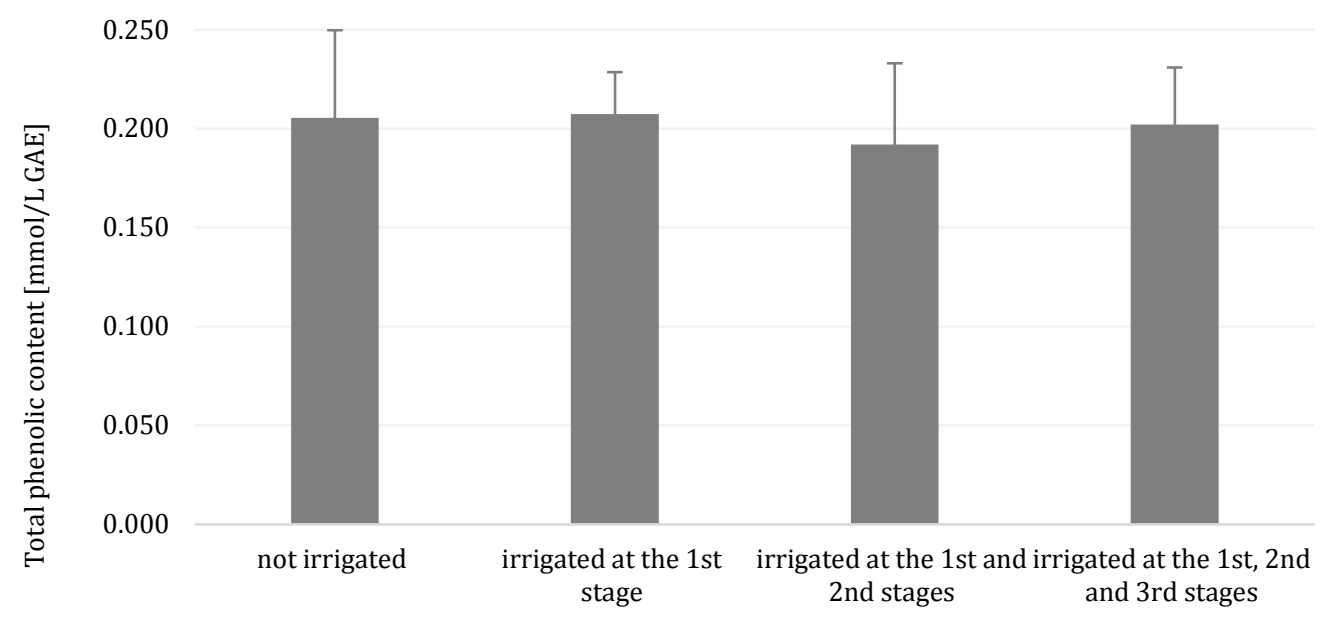

Figure 5 Total phenolic content of defatted hazelnuts irrigated at the different growth stages combinations.

\section{Conclusion}

The effect of supplementary irrigation on total phenolic contents and antioxidant capacity of hazelnut was performed for the first time in this study. The antioxidant capacity of hazelnut was affected by irrigation at the different growth stages, while irrigation program did not influence the total phenolic content of hazelnuts. Overall total antioxidant capacity increased by irrigation, therefore, it can be concluded that the irrigation could be a good agriculture practice to enhance of some bioactive compounds of hazelnuts kernels.

\section{References}

Alasalvar, C., Amaral, J. S., Shahidi, F., 2006. Functional Lipid Characteristics of Turkish Tombul Hazelnut
(Corylus avellana L.). Journal of Agricultural and Food Chemistry, 54, 10177-10183.

Alasalvar, C., Shahidi, F., 2009. Tree Nuts: Composition Phytochemicals and Health Effects. Taylor \& Francis Group Boca Raton London New York: CRC Press.

Altun, M., Çelik, S. E, Güçlü, K., Özyürek, M., Erçă̆, E., Apak, R., 2013. Total Antioxidant Capacity and Phenolic Contents of Turkish Hazelnut (Corylus avellana) Kernels and Oils. Journal of Food Biochemistry, 37(1): 53-61.

Amaral, J. S., Casal, S., Citov'a, I., Santos, A., Seabra, R. M., Oliveira, B. P. P., 2006. Characterization of several hazelnut (Corylus avellana L.) cultivars based in chemical, fatty acid and sterol composition. European Food Research and Technology, 222, 274-280. 
Arcan, I., Yemenicioğlu, A., 2009. Antioxidant activity and phenolic content of fresh and dry nuts with or without the seed coat. Journal of Food Composition and Analysis, 22(3): 184-188.

Crews, C., Hough, P., Godward, J., Brereton, P., Lees, M., Guiet, S., and Winkelmann, W., 2005. Study of the Main Constituents of Some Authentic Hazelnut Oils. Journal Agricultural Food Chemistry, 53(12), 48434852.

Cristofori, V., Muleo, R., Bignami, C., Rugini, E., 2014. Long term evaluation of hazelnut response to drip irrigation. Acta Horticulturae, 1052, 179-185.

Contini, M., Baccelloni S., Massantini, R. and Anelli, G., 2008. Extraction of natural antioxidants from hazelnut (Corylus avellana L.) shell and skin wastes by long maceration at room temperature. Food Chemistry, 110(3): 659-669.

Delgado, T., Malheiro, R., Pereira, J. A., Ramalhosa E., 2010. Hazelnut (Corylus avellana L.) kernels as a source of antioxidants and their potential in relation to other nuts. Industrial Crops and Products, 32(3): 621626.

FAO, 2019. FAOSTAT. (Web page: http://www.fao.org /faostat/en/\#data/QC), (Date accessed: 17.04.2019)

İslam, A, 2018. Hazelnut culture in Turkey. Akademik Ziraat Dergisi , 7 (2) , 259-266.

Kornsteiner, M., Wagner, K.-H., Elmadfa, I., 2006. Tocopherols and total phenolics in 10 different nut types. Food Chemistry, 98(2), 381-387.

Koyuncu M. A., Islam A., Kucuk M., 2005. Fat and fatty acid composition of hazelnut kernels in vacuum packages during storage, Grasas y Aceites, 56:263266

Krist S., Buchbauer G., Klausberger C., 2008, Lexikon der pflanzlichen Fette und Öle. Springer Verlag, Wien.

Külahçilar, A., Tonkaz, T., Bostan, S.Z., 2018. Effect of irrigation regimes by mini sprinkler on yield and pomological traits in 'Tombul' hazelnut. Acta Horticulturae, 1226, 301-308.

Li, H., Parry, J. W., 2011. Phytochemical Compositions, Antioxidant Properties, and Colon Cancer Antiproliferation Effects of Turkish and Oregon Hazelnut. Food and Nutrition Sciences, 02(10): 1142-1149.

Lipan, L., Moriana, A., López Lluch, D. B., Cano-Lamadrid, M., Sendra, E., Hernández, F., Vázquez-Araújo, L., Corell, M., Carbonell-Barrachina, Á. A., 2019.
Nutrition Quality Parameters of Almonds as Affected by Deficit Irrigation Strategies. Molecules, 24(14), 2646.

Marin, A., Rubio, J. S., Martínez, V., Gil, M. I., 2009. Antioxidant compounds in green and red peppers as affected by irrigation frequency, salinity and nutrient solution composition. Journal of the Science of Food and Agriculture, 89(8), 1352-1359.

Miraliakbari, H., Shahidi, F., 2008. Antioxidant activity of minor components of tree nut oils. Food Chemistry, 111(2): 421-427.

Pelvan, E., Alasalvar, C., Uzman, S., 2012. Effects of Roasting on the Antioxidant Status and Phenolic Profiles of Commercial Turkish Hazelnut Varieties (Corylus avellana L.). Journal of Agricultural and Food Chemistry, 60: 1218-1223.

Pernice, R., Parisi, M., Giordano, I., Pentangelo, A., Graziani, G., Gallo, M., Fogliano, V. and Ritieni, A., 2010. Antioxidants profile of small tomato fruits: Effect of irrigation and industrial process. Scientia Horticulturae, 126(2), 156-163.

Sahin, S., 2011. Bewertung der licht-induzierten Lipidstabilität von konventionellen und high-oleic Rapsölen supplementiert mit natürlichen Antioxidantien, Yüksek Lisans Tezi, Hamburg University of Applied Sciences, Hamburg

Sahin, S., Kılıç, Ö, Şengül, S., Perçin, S., 2019. Farklı İllerden Temin Edilen Fındık Zarının Bileşimi ve Antioksidan Etkinliğinin Araştırılması. Ordu Üniversitesi Bilim ve Teknoloji Dergisi, 9 (1): 2735 .

Sahin S., Tonkaz T., Oğurlu M. N., Uğurlu Z., 2017. Chemical Composition, Antioxidant Capacity and Phenolic Content of Hazelnut Fruits Grown in Different Countries, IX. International Congress on Hazelnut, 15-19 Ağustos, Samsun

Schmidt, N., Zinkernagel, J., 2017. Model and Growth Stage Based Variability of the Irrigation Demand of Onion Crops with Predicted Climate Change, Water, 9(9), 693.

Willcox, J. K., Ash, S. L., Catignani, G. L., 2004. Antioxidants and prevention of chronic disease. Critical Reviews in Food Science and Nutrition, 44(4): 275-295.

Yang, J., Liu, R. H., Halim, L., 2009. Antioxidant and antiproliferative activities of common edible nut seeds. LWT - Food Science and Technology, 42(1): 1-8. 